\title{
Informing Young Women about Computer Careers: Examining the Pervasiveness of the Geek Image
}

\section{Donna M. Grant, Linda V. Knight, and Theresa A. Steinbach DePaul University, Chicago, IL 60604-2301 USA}

\author{
dgrant@cti.depaul.edu; Iknight@cti.depaul.edu; \\ tsteinbach@cti.depaul.edu
}

\begin{abstract}
Organizations attempting to attract more women to the Information Technology field often focus on convincing young women that the computer field is not composed primarily of geeks and loners. However, relatively little prior research focuses on whether the geek or loner image is in fact a reality in the minds of young women. This research reports on the results of a study of 412 girls, ages sixteen through eighteen, in a major Midwestern United States city. The study found that, contrary to popular opinion, most of these girls do not view those who choose computer related careers as being geeks or loners. These results call for reassessment of resources currently allocated to combat the geek and loner image, particularly in large urban areas. The research also uncovers unexpected racial differences in how those who choose computer careers are perceived.
\end{abstract}

Material published as part of this publication, either on-line or in print, is copyrighted by the Informing Science Institute. Permission to make digital or paper copy of part or all of these works for personal or classroom use is granted without fee provided that the copies are not made or distributed for profit or commercial advantage AND that copies 1) bear this notice in full and 2) give the full citation on the first page. It is permissible to abstract these works so long as credit is given. To copy in all other cases or to republish or to post on a server or to redistribute to lists requires specific permission and payment of a fee. Contact Publisher@InformingScience.org to request redistribution permission. 